\title{
A reformulation of Murashige and Skoog medium (WPBS medium) improves embryogenesis, morphogenesis and transformation efficiency in temperate and tropical grasses and cereals
}

\author{
S. J. Dalton ${ }^{1}$ (D) \\ Received: 10 September 2019 / Accepted: 23 January 2020 / Published online: 19 February 2020 \\ (c) The Author(s) 2020
}

\begin{abstract}
Slow callus growth is a barrier to efficient genetic transformation in some gramineous species. A reformulation of Murashige and Skoog (MS) medium, with additional magnesium sulphate, potassium phosphate, copper sulphate, proline and glutamine, termed WPBS medium, has been developed which improves all aspects of in vitro culture when compared with MS based media. Embryogenic callus could be produced more rapidly from responsive genotypes of sixteen cereal, forage, model and energy grass species, whether using embryos, shoot tips or proliferated meristems as explants. Three species were not transformed due to contamination or unsuitable explant, but thirteen species were transformed using an identical Agrobacteriummediated transformation, selection and regeneration protocol, including Avena sativa and Oryza sativa. Readily transformable species such as Lolium perenne, Brachypodium distachyon and Festuca arundinacea and recalcitrant species such as Lolium temulentum and Miscanthus sinensis were reliably transformed, while two new species Phalaris arundinacea and viviparous Deschampsia cespitosa were transformed at the first attempt. It is hoped that the use of WPBS media and this general transformation protocol may help to improve the efficiency of grass and cereal transformation.
\end{abstract}

\section{Key Message}

WPBS medium and a general transformation protocol improves plant growth, embryogenic callus growth, genetic transformation and plant regeneration in a wide range of grass and cereal species.

Keywords Embryogenic callus $\cdot$ Transformation $\cdot$ Forage grasses $\cdot$ Model grasses $\cdot$ Energy grasses $\cdot$ Cereals

\section{Abbreviations}

BAP 6-Benzylaminopurine

cV Cultivar

2,4-D 2,4-Dichlorophenoxyacetic acid

FW Fresh weight

GOI Genes of interest

MS Murashige and Skoog

MS1.5P Miscanthus maintenance/rooting medium

MSO General maintenance/rooting medium

Communicated by Mohammad Faisal.

Electronic supplementary material The online version of this article (https://doi.org/10.1007/s11240-020-01784-8) contains supplementary material, which is available to authorized users.

S. J. Dalton

snd@aber.ac.uk

1 IBERS, Aberystwyth University, Aberystwyth, Wales, UK
NAA Naphthalene acetic acid

NS Not significant

OMM Avena meristem medium

PIG Particle inflow gun

PPT Phosphinothricin

RM Regeneration medium

WPBS Welsh Plant Breeding Station

\section{Introduction}

The induction of fast-growing, embryogenic callus is a pre-requisite for efficient genetic transformation in grasses and cereals and cultures have generally been grown on Murashige and Skoog (1962) medium (Wang et al. 2001). However, several important species are slow growing on this medium and Miscanthus species for instance are currently only transformed with low efficiency (Wang et al. 
2011; Hwang et al. 2014; Yoo et al. 2018). A model grass transformation system such as that devised for B. distachyon (Thole and Vain 2012) produces transformable callus in 6 weeks while most Miscanthus explants have barely started to grow by then.

Several compounds have been shown to improve embryogenic callus growth in particular grasses and cereals: magnesium chloride (Holme et al. 1997), silver nitrate (Frame et al. 2002), copper sulphate (Ha et al. 2001; Choi et al. 2001; Thole and Vain 2012), proline (Holme et al. 1997; Frame et al. 2002; Dalton 2013; Patel et al. 2013; Hwang et al. 2014) and glutamine (Zhang et al. 2013; Pawar et al. 2015) or shown to be rapidly depleted in cultures: potassium phosphate (Pepó and Tóth 2003).

These compounds have been assessed and combined in Miscanthus media to improve transformation efficiency (Dalton unpub) and positive results using these media with other grass and cereal species has led to the development and refinement of a modified basal medium for grasses and cereals generally (Dalton unpub). This modified MS medium, which contains additional magnesium sulphate, potassium phosphate, copper sulphate, proline and glutamine has been named WPBS medium.

During the development of WPBS medium, a single Agrobacterium-mediated transformation protocol was used where possible for all species. However, the explant used for callus induction depends on species. Immature embryos have normally been cultured for callus induction in annual species such as Brachypodium distachyon (Thole and Vain 2012), Lolium temulentum (Dalton et al. 1999) and Zea mays (Frame et al. 2002), while mature embryos were used in Oryza sativa (Shri et al. 2013). With Avena sativa however, panicles contain few immature embryos at the same suitable stage, but Maqbool et al. (2002) have devised a medium to induce multiple meristems from $A$. sativa shoot tips for direct transformation. Shoot tips containing the apical meristem have been routinely used to induce embryogenic callus from transformable genotypes of perennial, outbreeding grass species for many years (Dalton et al. 1998, 1999, 2003).

For Agrobacterium-mediated transformation, the infection and co-cultivation media devised for maize by Frame et al. (2002) were used, but modified by the addition of maltose (Patel et al. 2013) and the omission of myo-inositol, which was shown to reduce Agrobacterium tumefaciens infectivity (Zhang et al. 2013). Additional copper sulphate was also omitted as it had been shown to reduce Agrobacterium growth (Nawapan et al. 2009). These infection and co-cultivation media have long been used successfully in all routinely transformed species in this laboratory (Dalton unpub.) as has a regeneration medium (RM) devised for Dicanthium annulatum (Dalton et al. 2003).
This study used sixteen grass and cereal species to compare WPBS-based media with MS-based media at every stage of this general Agrobacterium-mediated transformation protocol.

\section{Materials and methods}

\section{Preliminary development of WPBS medium}

Over one hundred different formulations of MS medium were evaluated quantitively by determining embryogenic callus growth and subsequent shoot regeneration (data not shown). A rationale for developing the medium and a list of the concentrations of each compound tested is shown in Suppl. Text 1 and Suppl. Table 1. The final basal medium was defined and named WPBS medium to celebrate the 2019 centenary of the Welsh Plant Breeding Station. WPBS medium was compared directly against the control MS basal medium at every stage of transformation and was the main objective of this study.

A single transformation protocol was followed with all sixteen species, using the same Agrobacterium infection and co-cultivation media, and plant regeneration and rooting media. The only differences in the experimental protocol between species were the explants used to induce callus, the requirements for growth regulators such as 2,4-D and BAP in callus media and increased proline for Miscanthus, and the timing of callus induction regimes.

\section{Plant material}

Selected tissue culture responsive genotypes of perennial out-breeding grasses and responsive lines or cultivars of inbreeding grasses and cereals were used. These were Agrostis stolinifera L.[creeping bentgrass] cv Sefton genotype C120SeftonE (Dalton et al. 1998); Avena sativa L. [oat] cvs Bajka (Gasparis and Nadolska-Orczyk 2015) and Assinaboia; Brachypodium distachyon (L.) P.Beauv. [stiff brome] line BD21-3 (Vogel and Hill 2008); viviparous Deschampsia cespitosa (L.) P.Beauv.[tufted hairgrass] genotype ABY-Bs3667 (Dalton unpub.); Festuca arundinacea Schreb.[tall fescue] cv Aberystwyth S170 genotype CS20BN3 (Dalton et al. 1998; Bettany et al. 2003; Buanafina et al. 2015); Festuca rubra L. [red fescue] cv Barcrown genotype C123 BarcrownA0 (Dalton unpub.); Lolium multiflorum Lam.[Italian ryegrass] cv Trident genotype C38BB13 (Dalton et al. 1998, 1999; Bettany et al. 2003); Lolium perenne L.[perennial ryegrass] cv Aberystwyth S23 genotype CS128S23Z (Dalton et al. 1998, 1999); Lolium temulentum L.[darnel] genotype ABY-Ba3081 (Dalton and Thomas 1992; Dalton et al. 1999); Miscanthus sinensis Andersson genotype Suegen14 (Dalton 2013); Miscanthus floridulus 
genotype ABY-Mb1125 (Dalton 2013); Miscanthus sacchariflorus (Maxim.) Franch. genotype Robustus (Dalton 2013); Oryza sativa [rice] cvs IR-64 (Shri et al. 2013), IET4786 (Shri et al. 2013) and Italian long grain; Phalaris arundinacea L.[reed canary grass] cv Bamse genotypes C416RCG9, C372RCGI9-8, C372RCGI9-10 (Dalton unpub.); Poa pratensis L. [smooth-stalked meadow grass] apomictic genotype C8 A24 (Robson et al. 2004); Zea mays L.[maize] genotype A188 (Ishida et al. 1996).

\section{WPBS and MS culture media}

The MS control medium used throughout was a modified MS medium (Duchefa M0245) containing $1 \mathrm{mgl}^{-1}$ thiamine. WPBS medium was based on this MS medium, but used three-quarter strength macro-elements and contained extra potassium, phosphate, sulphate, magnesium, copper and thiamine as well as proline and glutamine as a basal medium (Table 1).

For Agrobacterium-mediated transformation three WPBS stock solutions were required, one with myo-inositol (WPBS-A) for normal growth, selection and regeneration, one without myo-inositol (WPBS-B) for callus induction and a third (WPBS-C) without myo-inositol and copper sulphate for Agrobacterium infection and co-cultivation. For particle bombardment and propagation WPBS-A was used throughout.

The three WPBS compositions A, B and C (Suppl. Table 2) were made as stock solutions for $100 \mathrm{~L}$ of final medium (Suppl. Table 3).

It should be noted that WPBS solution is blue when mixed, due to the Biuret reaction between proline and copper

Table 1 WPBS medium compared with full strength and 3/4 strength macro-elements Murashige and Skoog medium

\begin{tabular}{|c|c|c|c|}
\hline Ingredient $\mathrm{mgl}^{-1}$ and final molarity $\mathrm{mM}$ & $\begin{array}{l}\text { Control medium Modified MS } \\
\text { (Duchefa M0245) }\end{array}$ & $\begin{array}{l}\text { MS 3/4 salts } \\
\text { (Duchefa M0234) }\end{array}$ & $\begin{array}{l}\text { WPBS medium } \\
\text { (M0234 with WPBS } \\
\text { solution) }\end{array}$ \\
\hline $\begin{array}{l}\mathrm{CaCl}_{2} \\
\mathrm{MW} 111\end{array}$ & $\begin{array}{l}332.02 \\
3\end{array}$ & $\begin{array}{l}249.02 \\
2.24\end{array}$ & $\begin{array}{l}249.02 \\
2.24\end{array}$ \\
\hline $\begin{array}{l}\mathrm{KH}_{2} \mathrm{PO}_{4} \\
\mathrm{MW} 136\end{array}$ & $\begin{array}{l}170 \\
1.25\end{array}$ & $\begin{array}{l}127.5 \\
0.94\end{array}$ & $\begin{array}{l}277.5 \\
2.04\end{array}$ \\
\hline $\begin{array}{l}\mathrm{KNO}_{3} \\
\mathrm{MW} 101\end{array}$ & $\begin{array}{l}1900 \\
18.79\end{array}$ & $\begin{array}{l}1425 \\
14.09\end{array}$ & $\begin{array}{l}1425 \\
14.09\end{array}$ \\
\hline $\begin{array}{l}\mathrm{MgSO}_{4} \\
\mathrm{MW} 120\end{array}$ & $\begin{array}{l}180.54 \\
1.5\end{array}$ & $\begin{array}{l}136.01 \\
1.13\end{array}$ & $\begin{array}{l}426 \\
3.54\end{array}$ \\
\hline $\begin{array}{l}\mathrm{NH}_{4} \mathrm{NO}_{3} \\
\mathrm{MW} 80\end{array}$ & $\begin{array}{l}1650 \\
20.61\end{array}$ & $\begin{array}{l}1237.5 \\
15.46\end{array}$ & $\begin{array}{l}1237.5 \\
15.46\end{array}$ \\
\hline $\begin{array}{l}\mathrm{CuSO}_{4} 5 \mathrm{H}_{2} \mathrm{O} \\
\mathrm{MW} 250\end{array}$ & $\begin{array}{l}0.025 \\
0.1 \mu M\end{array}$ & $\begin{array}{l}0.025 \\
0.1 \mu M\end{array}$ & $\begin{array}{l}0.625 \\
2.5 \mu M^{\mathrm{a}}\end{array}$ \\
\hline Total weight of macro elements & 4232 & 3175 & 3615 \\
\hline Proline & & & 700 \\
\hline Glutamine & & & 125 \\
\hline Thiamine & 1 & & 1 \\
\hline Myo-inositol & 100 & & $100^{\mathrm{b}}$ \\
\hline Nicotinic acid & 0.5 & & 0.5 \\
\hline Pyridoxine $\mathrm{HCl}$ & 0.5 & & 0.5 \\
\hline Glycine & 2 & & 2 \\
\hline Micro elements & MS & MS & $\mathrm{MS}^{\mathrm{c}}$ \\
\hline \multicolumn{4}{|l|}{ Total molarity (mM) } \\
\hline $\mathrm{Ca}$ & 3 & 2.24 & 2.24 \\
\hline $\mathrm{Cu}$ & 0.1 & 0.1 & 2.5 \\
\hline $\mathrm{K}$ & 20.04 & 15.03 & 16.13 \\
\hline $\mathrm{Mg}$ & 1.5 & 1.13 & 3.54 \\
\hline NO3 & 39.4 & 29.55 & 29.55 \\
\hline PO4 & 1.25 & 0.94 & 2.04 \\
\hline $\mathrm{SO} 4$ & 1.5 & 1.13 & 3.54 \\
\hline
\end{tabular}

${ }^{\mathrm{a}}$ Omitted from WPBS-C

${ }^{\mathrm{b}}$ Omitted from WPBS-B and WPBS-C by use of Chu's N6 vitamins

${ }^{\mathrm{c}}$ As for Murashige and Skoog except additional $\mathrm{CuSO}_{4}$ 
sulphate, but this did not affect medium $\mathrm{pH}$ or plant growth. Stock solutions were immediately frozen in $40 \mathrm{ml}$ aliquots and were added to media as required before autoclaving. For each litre of final WPBS medium, $20 \mathrm{mls}$ of WPBS-A, $\mathrm{B}$ or $\mathrm{C}$ stock solution was added to $3.25 \mathrm{~g}$ of three-quarter strength macro-elements MS medium without vitamins (Duchefa M0234) and the $\mathrm{pH}$ adjusted to 5.6. Media for all purposes and species (Table 2) were then autoclaved at $121{ }^{\circ} \mathrm{C}$ for $15 \mathrm{~min}$, except for Agrobacterium infection and co-cultivation media, which were filter-sterilised.

\section{Comparison of WPBS and MS medium for plant growth}

Brachypodium distachyon and L. temulentum seeds and A. sativa caryopses from de-husked seed were surface sterilized in $100 \%$ commercial sodium hypochlorite bleach (4.47\% available chlorine) for 30-60 min, rinsed in sterile water, imbibed overnight at $4{ }^{\circ} \mathrm{C}$ and re-sterilised with $20 \%$ bleach for $10 \mathrm{~min}$ before use. Ten excised mature embryos of Brachypodium and Lolium and caryopses of Avena were cultured per $90 \mathrm{~mm}$ Petri-dish (7-12 replicates) on MS and WPBS-A maintenance medium (MSO) (Table 2) and the seedling dry matter determined after 3 weeks (or 6 weeks for Brachypodium). Single tillers from in vitro stock plantlets of $M$. floridulus grown in liquid Miscanthus maintenance medium (MS1.5P) with MS (3 tillers) and WPBS-A (13 tillers) were weighed after 7 weeks growth. All cultures were grown at $25^{\circ} \mathrm{C}$ in continuous light of $\sim 100 \mu \mathrm{E} \mathrm{m}^{-2} \mathrm{~s}^{-1}$.

\section{Comparison of WPBS and MS media for callus induction}

\section{Explants used for callus induction}

Callus induction from annual grass species and cereals was through immature embryo culture of transformable lines. Callus induction from perennial, outbreeding species was through shoot tip cultures containing the apical meristem from in vitro plantlets of transformable genotypes. Calli could also be induced from proliferating meristematic cultures of some species. Calli were grown at $25^{\circ} \mathrm{C}$ in the dark (Brachypodium and Oryza at $28{ }^{\circ} \mathrm{C}$ ).

\section{Embryo culture of annual grasses and cereals}

Spikelets from immature inflorescences of $B$. distachyon and $L$. temulentum stored at $4{ }^{\circ} \mathrm{C}$ overnight, were surface sterilized in $100 \%$ commercial sodium hypochlorite bleach (4.47\% available chlorine) for 20-30 min and rinsed in sterile water. Semi-translucent immature embryos, Lolium $(0.5-1 \mathrm{~mm})$ and Brachypodium $(0.2-0.5 \mathrm{~mm})$, were cultured with the scutellum uppermost. Mature embryos of rice were cultured from seed which had been surface-sterilized twice as described.

\section{Shoot tip culture of perennial grasses}

Shoot tips $(0.3-0.5 \mathrm{~mm})$ containing the apical meristem were cultured from sterile in vitro stock plants of perennial grasses, growing on MS or WPBS-A maintenance medium (MSO) or Miscanthus propagation medium (Table 2). Calli were grown for about 5 weeks and sub-cultured to fresh medium at least twice before cultures of up to 7 days from the last subculture were used for transformation. Three replicate dishes of twenty $F$. arundinacea, $L$. multiflorum and $L$. perenne shoot tip calli growing on MS and WPBS-B medium were compared after 31,51 and 60 days.

\section{Proliferating meristem culture of Avena sativa}

Seedlings were germinated from surface sterilized seed on WPBS-A maintenance medium (MSO). In vitro seedling shoot tips $(0.3-0.5 \mathrm{~mm})$ were cultured directly on WPBS$\mathrm{B}$ Avena callus induction medium or were first cultured on WPBS-A Avena meristem proliferation medium (OMM) (Table 2) to produce additional meristematic tissue for callus induction. Cultures were grown in the light at $25^{\circ} \mathrm{C}$ for 5 weeks before sub-culture to fresh medium and were used for up to 2 months. Small meristematic clusters were transferred to callus induction medium (Table 2). This approach was also applicable to $F$. arundinacea, $L$. perenne and $L$. temulentum. To compare shoot-tips and meristem clusters for Avena callus induction, ten shoot tips and ten meristematic clusters were cultured on WPBS-B Avena callus medium (5 replicates each). The calli were gathered and weighed at subculture to fresh medium after 33,46 and 52 days.

\section{Comparison of WPBS with MS media using different callus induction regimes}

Most perennial grasses required a period of at least 4 weeks of initial shoot tip callus induction followed by several subcultures totaling 9 or more weeks (Suppl. Table 4). Immature embryos of the fast-growing annual species $B$. distachyon, were cultured with a 3 week, 2 week, 1 week subculture regime, totaling only 6 weeks in culture before transformation. The rapid growth of Brachypodium on WPBS medium led to five simpler regimes being tested to reduce sub-culturing and the total time in culture. At least two experiments were performed with each regime with 5-52 replicate dishes of $\sim 25$ embryos on MS and WPBS media.

With L. temulentum, immature embryo cultures were normally transformed after a few days culture, as in maize (Frame et al. 2002). Replicate dishes of $\sim 25$ embryos (148 dishes with WPBS medium, 60 dishes with MS medium) 
Table 2 WPBS culture media and explants used in different grass species for normal growth, propagation, callus induction, transformation and regeneration. Control media were made using modified MS medium (Duchefa M0245) instead of WPBS medium. All media were autoclaved for $15 \mathrm{~min}$ at $121{ }^{\circ} \mathrm{C}$, solidified with $0.03 \%$ Gelrite and adjusted to $\mathrm{pH} 5.6$ unless stated otherwise

\begin{tabular}{|c|c|c|}
\hline Purpose of culture medium and species & Explant & WPBS culture medium per litre \\
\hline $\begin{array}{l}\text { 1. Shoot tip culture, rooting and maintenance } \\
\text { medium (MSO) }\end{array}$ & Shoot tips, shoots & WPBS-A, $3 \%$ sucrose \\
\hline $\begin{array}{l}\text { 2. Avena meristem medium (OMM) } \\
\text { (Avena sativa, Lolium perenne, } \\
\text { L. temulentum, Festuca arundinacea) }\end{array}$ & Shoot tips from seedlings or plantlets on MSO & WPBS-A, $3 \%$ maltose, $0.5 \mathrm{mg} 2,4-\mathrm{D}, 2 \mathrm{mg}$ BAP \\
\hline \multicolumn{3}{|l|}{ 3. Pre-transformation callus induction media } \\
\hline Lolium perenne & $\begin{array}{l}\text { Shoot tips from plantlets on MSO or meristem } \\
\text { clusters from OMM }\end{array}$ & WPBS-B, 3\% maltose, $5 \mathrm{mg}$ 2,4-D, $0.5 \mathrm{mg}$ BAP \\
\hline Lolium temulentum & $\begin{array}{l}\text { Immature embryos } 0.5-1 \mathrm{~mm} \text { or meristem } \\
\text { clusters from OMM }\end{array}$ & \\
\hline Avena sativa & Meristem clusters from OMM & \\
\hline Festuca arundinacea, & $\begin{array}{l}\text { Shoot tips from plantlets on MSO or meristem } \\
\text { clusters from OMM }\end{array}$ & WPBS-B, $3 \%$ maltose, $4 \mathrm{mg}$ 2,4-D \\
\hline $\begin{array}{l}\text { Agrostis stolonifera, Deschampsia cespitosa, } \\
\text { Festuca. rubra, Lolium multiflorum, Poa } \\
\text { pratensis, }\end{array}$ & Shoot tips from plantlets on MSO & WPBS-B, $3 \%$ maltose, $3 \mathrm{mg}$ 2,4-D \\
\hline Phalaris arundinacea & $\begin{array}{l}\text { Shoot tips from plantlets on MSO or meristem } \\
\text { clusters from OMM }\end{array}$ & \\
\hline Oryza sativa & $\begin{array}{l}\text { Mature embryos (shoot tips and OMM not } \\
\text { successful) }\end{array}$ & \\
\hline Brachypodium distachyon & $\begin{array}{l}\text { Immature embryos } 0.2-0.5 \mathrm{~mm} \text { (shoot } \\
\text { tips and OMM not successful) }\end{array}$ & WPBS-B, $3 \%$ maltose, $2.5 \mathrm{mg}$ 2,4-D \\
\hline Zea mays & $\begin{array}{l}\text { Immature embryos } 1.5-2 \mathrm{~mm} \text { (shoot tips not } \\
\text { successful) }\end{array}$ & WPBS-B, $3 \%$ maltose, $2 \mathrm{mg}$ 2,4-D \\
\hline \multicolumn{3}{|l|}{ 4. Transformation media } \\
\hline Agrobacterium infection medium (liquid) ${ }^{\mathrm{a}}$ & Immature embryos, calli, cell suspensions & $\begin{array}{l}\text { WPBS-C, } 6.84 \% \text { sucrose, } 3.6 \% \text { glucose, } 2.5 \mathrm{mg} \\
2,4-\mathrm{D}, \mathrm{pH} 5.2\end{array}$ \\
\hline $\begin{array}{l}\text { Agrobacterium co-cultivation } \\
\text { medium (liquid) }\end{array}$ & Immature embryos, calli, cell suspensions & $\begin{array}{l}\text { WPBS-C, } 6 \% \text { maltose, } 300 \mathrm{mg} \text { cysteine, } \\
2.5-5 \mathrm{mg} 2,4-\mathrm{D}, \mathrm{pH} 5.2\end{array}$ \\
\hline Osmotic bombardment medium & Calli, cell suspensions & WPBS-A, 3\% maltose, $9 \%$ sorbitol, $3 \mathrm{mg}$ 2,4-D \\
\hline \multicolumn{3}{|l|}{ 5. Post transformation media } \\
\hline Callus selection medium & Agrobacterium treated or bombarded calli & $\begin{array}{l}\text { WPBS-A, } 3 \% \text { sucrose, } \mathrm{pH} 5.6 \text {, growth regula- } \\
\text { tors as for calli above }\end{array}$ \\
\hline Regeneration medium (RM) & Calli & WPBS-A, $3 \%$ maltose, $1 \mathrm{mg}$ BAP, $1 \mathrm{mg}$ NAA \\
\hline Rooting medium (MSO) & Shoot tips, shoots & WPBS-A, $3 \%$ sucrose \\
\hline \multicolumn{3}{|l|}{$\begin{array}{l}\text { 6. Miscanthus media where different } \\
\text { for Miscanthus sinensis, M.floridulus, } \\
\text { M.sacchariflorus }\end{array}$} \\
\hline $\begin{array}{l}\text { Shoot tip culture, rooting and maintenance } \\
\text { medium (liquid) (MS1.5P) }\end{array}$ & Shoot tips, shoots & WPBS-A, $3 \%$ sucrose, $0.8 \mathrm{~g}$ proline ( $1.5 \mathrm{~g}$ total $)$ \\
\hline Propagation medium (liquid) & Shoots & $\begin{array}{l}\text { WPBS-A, } 3 \% \text { sucrose, } 0.3 \mathrm{mg} \text { BAP, } 0.8 \mathrm{~g} \text { pro- } \\
\text { line }(1.5 \mathrm{~g} \text { total })\end{array}$ \\
\hline Pre-transformation callus induction medium & $\begin{array}{l}\text { Shoot tips from plantlets on propagation } \\
\text { medium }\end{array}$ & $\begin{array}{l}\text { WPBS-B, } 3 \% \text { maltose, } 3 \mathrm{mg} 2,4-\mathrm{D}, 0.1 \mathrm{mg} \\
\text { BAP, } 0.7 \mathrm{~g} \text { proline }(1.4 \mathrm{~g} \text { total })\end{array}$ \\
\hline Osmotic bombardment medium & Calli & $\begin{array}{l}\text { WPBS-A, } 3 \% \text { maltose, } 5.5 \% \text { mannitol, } 5.5 \% \\
\text { sorbitol, } 3 \text { mg 2,4-D }\end{array}$ \\
\hline Post-transformation callus selection medium & Agrobacterium treated or bombarded calli & $\begin{array}{l}\text { WPBS-A, } 3 \% \text { sucrose, } 3 \mathrm{mg} 2,4-\mathrm{D}, 0.1 \mathrm{mg} \\
\text { BAP, } 0.7 \mathrm{~g} \text { proline }(1.4 \mathrm{~g} \text { total })\end{array}$ \\
\hline
\end{tabular}

${ }^{\mathrm{a}}$ Filter sterilised through $0.2 \mu \mathrm{M}$ filter 
were cultured in 21 separate experiments to establish the optimum culture period. The callusing embryos were gathered, weighed and transformed after 6 to 13 days culture.

\section{Comparison of WPBS with MS media for Agrobacterium-mediated transformation and the effect of heat shock, vacuum infiltration and Agrobacterium immersion}

Calli for Agrobacterium transformation were induced on MS or WPBS-B based media containing maltose using various explants (Table 2). Most transformations were with genes of interest (GOI), but some used constructs containing the gus A gene. These were gus A and hpt in pBRACT204, (Harwood et al. 2009), in Agrobacterium strain AGL1; gus A and bar in pTF102 in Agrobacterium strain EHA105 (Frame et al. 2002), and gus A, hpt and nptII in pTOK233 in Agrobacterium strain LBA4404 (Hiei et al. 1994). For each species, the construct with the most effective selection gene was used.

Agrobacterium was grown on solid YEP medium (Frame et al. 2002) for $24 \mathrm{~h}$ with antibiotics $\left(25 \mathrm{mgl}^{-1}\right.$ rifampicin and e.g. $50 \mathrm{mgl}^{-1}$ hygromycin) at $25^{\circ} \mathrm{C}$ and then suspended at an $\mathrm{OD}_{600}$ of 0.6 in MS or WPBS-C based sucrose/glucose infection medium devised for maize (Frame et al. 2002) containing $200 \mu \mathrm{M}$ acetosyringone and $0.02 \%$ Pluronic F68. (Table 2). The culture was shaken gently for $16-20 \mathrm{~h}$ at $25^{\circ} \mathrm{C}$ to maximise infectivity (Xi et al. 2018).

Callus (1-2 g) or $\sim 25$ callusing embryos were collected in $2 \mathrm{ml}$ infection medium and heat shocked in a water bath at $43{ }^{\circ} \mathrm{C}$ for $3 \mathrm{~min}$ before adding $10-15 \mathrm{ml}$ of Agrobacterium suspension. For most experiments, the calli were collected in Agrobacterium suspension before vacuum infiltration with three short pulses at $711 \mathrm{~mm}(28 \mathrm{in}) \mathrm{Hg}$. In two experiments with L. temulentum, the Agrobacterium suspension was simply added to the calli on the callus medium to immerse them for the infection period. Calli were incubated with Agrobacterium for 30-40 min and dried on $85 \mathrm{~mm}$ filter papers in open Petri-dishes for 20-30 min. The dry calli were co-cultivated for 3 days on three $85 \mathrm{~mm}$ filter papers wetted with $3 \mathrm{ml}$ co-cultivation medium containing $200 \mu \mathrm{M}$ acetosyringone at $25{ }^{\circ} \mathrm{C}$ in the dark. Stacks of Petri-dishes were wrapped in clingfilm. The MS or WPBS-C based cocultivation medium contained $6 \%$ maltose as devised for Lolium (Patel et al. 2013) with cysteine as used in maize (Frame et al. 2002) (Table 2).

\section{Comparison of WPBS with MS media for callus selection}

After 3 days co-culture with Agrobacterium, the calli were transferred to MS or WPBS-A callus selection media (Table 2) with $75 \%$ of the final concentration of hygromycin, PPT or paromomycin (Suppl. Table 5). The selection media contained sucrose, as maltose allowed non-transformed calli to survive strong selection in Brachypodium. Meropenum $\left(50 \mathrm{mgl}^{-1}\right)$ was used as the most effective antibiotic against Agrobacterium, when combined with Timentin $\left(100 \mathrm{mgl}^{-1}\right)$. Calli were cultured in the dark at $25{ }^{\circ} \mathrm{C}$ (Brachypodium and Oryza at $28{ }^{\circ} \mathrm{C}$ ) for 3-4 weeks.

\section{Comparison of WPBS with MS media for plant regeneration}

Calli from callus selection media were transferred to selective MS or WPBS-A RM regeneration medium (Table 2) with $100 \%$ selection concentration (Suppl. Table 5) and grown in the light $\left(\sim 100 \mu \mathrm{E} \mathrm{m}^{-2} \mathrm{~s}^{-1}\right)$ at $25^{\circ} \mathrm{C}$ for $3-4$ weeks until shoots had regenerated. These were transferred to selective MS or WPBS-A based MSO or liquid MS1.5P Miscanthus maintenance/rooting media (Table 2) and grown under the same conditions. Rooted plants were transferred to soil in containment glasshouse or controlled growth room conditions under polythene for 1 week.

\section{Transformation by particle bombardment}

In addition to Agrobacterium transformation, calli from different species were also transformed by particle bombardment. Calli were bombarded with $0.6 \mu \mathrm{m}$ gold particles coated with plasmid DNA, containing various GOI, at 7.5 bar in a Particle Inflow Gun (PIG) (Finer et al. 1992) after $6 \mathrm{~h}$ on high osmotic potential medium ( $9 \mathrm{~h}$ on a higher osmotic potential medium for Miscanthus) (Table 2), using WPBS-A media only. A. sativa calli were co-transformed with GOI and pUBA (Toki et al. 1992). Transgenic F. arundinacea, $L$. temulentum and $B$. distachyon calli were retransformed with GOI and pBKS (Dalton et al. 2011). After $24 \mathrm{~h}$, bombarded calli were transferred to callus selection media with $75 \%$ selection concentration (Suppl. Table 5) and thereafter treated as for Agrobacterium treated callus, but without Meropenum or Timentin antibiotics.

\section{Confirmation of gene expression}

Most experiments were performed with GOI in collaboration with other researchers and transformed plants were confirmed by PCR, generally of the selective gene. Transformed plants in experiments with the gus A constructs were confirmed by survival under $100 \%$ selection and GUS expression in leaf samples incubated in X-Gluc solution (Dalton et al. 1998). 


\section{Statistical analysis}

T-tests and the Pearson co-efficient correlation between independent means were performed respectively using.

https://www.socscistatistics.com/tests/studentttest/ default 2 .aspx

https://www.socscistatistics.com/tests/pearson/defau lt2.aspx

\section{Results}

\section{WPBS medium increases plant growth}

The dry matter of L. temulentum, B. distachyon and A. sativa seedlings germinated on WPBS medium was significantly increased $(\mathrm{P} \leq 0.01)$ by at least $20 \%$ over MS medium (Fig. 1a). Seedlings on WPBS medium had longer roots and were more robust (Fig. 1b, c). Single tillers of M. floridulus in WPBS medium also had increased plantlet fresh weight $(\mathrm{FW})(\mathrm{P}=0.025)$, but the mean tiller number per plantlet was not increased.

\section{WPBS medium increases callus production and reduces culture time}

\section{Miscanthus species}

Miscanthus calli of all three species tested were slow to establish embryogenic calli, which were generally produced as a secondary development, following primary watery or friable callus growth (Suppl. Fig. 1a). WPBS medium was originally devised for Miscanthus and while there was no difference in the proportion of explants which produced embryogenic callus on MS or WPBS medium (Fig. 2a), the net growth of embryogenic callus was significantly higher $(\mathrm{P} \leq 0.01)$ on WPBS medium with no loss of quality (Fig. 3a). Established callus growth was as high as in other species (Fig. 3b), but a comparison of net growth rates over several experiments showed that sub-culturing more than $0.25 \mathrm{~g} \mathrm{FW}$ of callus significantly reduced $(\mathrm{P} \leq 0.01)$ callus growth rate (Suppl. Fig. 2a).

\section{Other perennial grass species}

Callus growth on WPBS medium was also increased in $L$. perenne (Fig. 2b), F. arundinacea (Fig. 2c) and L. multiflorum, compared with MS medium, but statistically significant differences could not be established due to large variations between replicate dishes (Fig. 3b). Callus induction in perennial species was generally slower than in annual species (Suppl. Fig. 3).

\section{Lolium temulentum}

The FW of calli from immature embryos was significantly higher at every time point over 6-13 days when cultured on WPBS medium than on MS medium $(\mathrm{P} \leq 0.01)$ (Figs. $2 \mathrm{~d}$, $3 c)$. Growth rates slowed by day 13 , but even after 5 weeks the difference in growth was notable (Suppl. Fig. 1b).

\section{Brachypodium distachyon}

Only a proportion of cultured immature embryos produced embryogenic callus and at 3 weeks, this was $55 \%$ of embryos on WPBS medium, compared with $36 \%$ on MS medium $(\mathrm{P} \leq 0.01)$ (Fig. 4a, Suppl. Fig. 1c). By 4 weeks this had increased to $71 \%$ of embryos on WPBS medium $(\mathrm{P} \leq 0.01)$, and $41 \%$ on MS medium (NS). The FW of embryogenic callus was also significantly higher on WPBS medium after 3 and 4 weeks and increased significantly over the final week (all $\mathrm{P} \leq 0.01$ ).

Immature embryos were normally cultured using a threetwo-one-week (3-2-1) subculture regime with two subcultures. The final FW of callus from 100 cultured embryos on WPBS medium was nearly $70 \%$ higher $(\mathrm{P} \leq 0.01)$ than on MS medium (Fig. 4b). This was partly due to a higher proportion of embryos responding on WPBS medium. However, the $\mathrm{FW}$ of callus from 100 responsive embryos was also $24 \%$ higher $(\mathrm{P} \leq 0.01)$. At least half of the growth occurred during the last week of culture and net growth was found to be negatively correlated $(\mathrm{R}=-0.7, \mathrm{P} \leq 0.01)$ with the callus inoculation density. However, despite a higher inoculation density, embryogenic callus cultured on WPBS medium had a higher net growth (2.6-fold) than on MS medium (2.1-fold).

The increase in growth using WPBS medium led to shorter regimes with a single subculture being tested. The amount of callus produced on WPBS medium was significantly higher $(\mathrm{P} \leq 0.05)$ than on MS medium in every regime compared (Fig. 4b). A four-one-week (4-1) regime allowed more embryos to develop and produced $17.8 \mathrm{~g}$ of embryogenic callus per 100 cultured embryos (Figs. 2e, 4b). This approached the $20.8 \mathrm{~g}$ of callus produced by the control MS three-two-one-week regime, but with only one subculture.

Shoot tips from sterile seedlings were also cultured to induce callus, but only $10 \%$ responded and the calli after a five-two-one-week regime were not successfully transformed.

\section{Avena sativa}

Shoot apical meristems from sterile seedlings were easier to culture than immature embryos. Shoot-tip-derived calli 
on WPBS based medium grew faster than those on MS medium ( $\mathrm{P}=0.04-0.10)$ (Fig. 3d).

WPBS based Avena meristem medium (OMM) (Table 2) was used to proliferate the shoot meristems (Fig. 5a) before culture on callus induction medium (Fig. 2f). Meristem-cluster-derived calli grew faster than shoot-tipderived calli with each subculture (Fig. 5b) $(\mathrm{P}=0.28$ at 33 days, $\mathrm{P}=0.07$ at 46 days, $\mathrm{P}=0.06$ at 52 days). A major benefit of this method was the abundance of meristematic tissue for culture. The OMM medium was also successful with $F$. arundinacea, L. perenne (both $\mathrm{P} \leq 0.01$ ), L. temulentum and P. arundinacea (Suppl. Fig. 1d), but not with $B$. distachyon and $O$. sativa (data not shown).

\section{Oryza sativa and Zea mays}

In $O$. sativa, seedling shoot-tip derived calli from all three varieties used were slower growing and less embryogenic than calli from mature embryos, (Suppl. Fig. 1e). Large differences in callus growth were found beween WPBS and MS media from 4 to 10 weeks, especially with matureembryo-derived calli (Suppl. Fig. 1f), but the number of cultures studied was too small to establish many significant differences (Suppl. Fig. 2b).

In Z. mays, immature embryo (Suppl. Fig. 1g) and seedling shoot-tip derived callus of A188 grew well on WPBS medium over 5 weeks. However only immature embryos produced regenerable type II embryogenic callus suitable for transformation.

\section{WPBS medium increases plant regeneration and rooting}

Embryogenic calli from the responsive genotypes of all the species tested, regenerated well on the control MS RM regeneration medium, but in experiments with $B$. distachyon, L. perenne and $M$. sinensis, regeneration was even more frequent on WPBS-A RM medium (Fig. 6a, b, c). M. sinensis and M. floridulus callus cultures remained regenerative for at least 8 months and albino shoots were very rarely produced. Shoot-tip-derived callus of $P$. arundinacea (Fig. 6d) and proliferated-meristem-derived callus of A. sativa (Fig. 6e) regenerated vigorously on the same medium, as did mature-embryo-derived callus of $O$. sativa and immature-embryo-derived callus of Z. mays. However, shoot-tip-derived callus of both species was less embryogenic and $O$. sativa callus regenerated poorly (Suppl. Fig. 1h), while Z. mays callus turned green but did not regenerate. Anther-derived calli of the three Miscanthus species and A.sativa also regenerated on WPBS RM medium (Suppl. Fig. 1i, j).

\section{WPBS medium increases Agrobacterium mediated transformation efficiency}

In all direct comparisons of transformations of six species between MS and WPBS media, the amount of callus produced and the transformation efficiency, in terms of plants per gram of callus, or plants per explant, was always higher when WPBS media were used (Table 3a, Suppl. Table 6a). Overall, the percentage improvements in transformation efficiency (plants per gram callus) of the six species (Table 3a) comparing WPBS and MS control media was significant $(P=0.02)$.

\section{Miscanthus species}

With improved callus growth rate, transformation by Agrobacterium as well as bombardment became possible, though at a low frequency except in the most responsive M. sinensis genotype, Suegen 14 and only by using WPBS media (Table 3a, Suppl. Table 6a, g). Hygromycin selection of calli was clear-cut in $M$. sinensis transformed with the plasmid construct pBRACT204 (Fig. 7a), but in regenerated plants (Suppl. Fig. 6a) GUS activity was restricted to stomata and leaf hairs. GUS activity was stronger and more wide-spread in mature leaves of M. floridulus (Suppl. Figs. 5a, 6b), but hygromycin resistant plantlets of $M$. sacchariflorus (Suppl. Fig. 6b) did not express GUS in any cells.

\section{Lolium perenne}

Significantly more GUS expressing plants were recovered from callus from the same number of explants using WPBS compared with MS media (Table 3a, Fig. 7b, Suppl. Fig. 5b). In this experiment, additional copper sulphate in infection and co-cultivation media appeared to reduce efficiency in WPBS grown cultures (Table 3b, Suppl. Fig. 6c) and although the number of plants transformed per replicate (1-2 g callus) was not statistically significant, it was not beneficial and was removed. Although not directly compared, using the Avena meristem medium (OMM) to proliferate meristematic tissue in L. perenne (and F. arundinacea) also improved transformation efficiency in terms of transformants per explant, but not transformants per gram of callus (Table 3c). The number of plants produced per replicate Agrobacterium treatment was significantly higher in Festuca $(\mathrm{P} \leq 0.05)$. In other experiments with $L$. perenne, older calli were shown to have a lower transformation efficiency per $\mathrm{g}$ than calli produced in a 4-2-1-week subculture regime (Table 3d). 
Table 3 Comparisons a-f of MS control and WPBS media, callus culture regimes and transformation treatments in Agrobacterium mediated transformations of various grass species using genes of interest or gus A

\begin{tabular}{|c|c|c|c|c|c|c|c|c|}
\hline Species & $\begin{array}{l}\text { Medium and } \\
\text { treatment }\end{array}$ & $\begin{array}{l}\text { No. of } \\
\text { explants or } \\
\text { embryos }\end{array}$ & Timing & $\begin{array}{l}\text { Total weight } \\
\text { of callus (g) }\end{array}$ & $\begin{array}{l}\text { GUS or PCR } \\
\text { pos plants or } \\
\text { (calli) }\end{array}$ & $\begin{array}{l}\text { Plants } \\
\text { per g } \\
\text { callus }\end{array}$ & $\begin{array}{l}\text { Plants per } \\
\text { explant }\end{array}$ & $\begin{array}{l}\text { Significance } \\
\text { between plant } \\
\text { numbers per } \\
\text { replicate dish }\end{array}$ \\
\hline
\end{tabular}

(a) Comparison of MS control and WPBS media and different callus culture regimes using gus A

\begin{tabular}{|c|c|c|c|c|c|c|c|c|}
\hline L. perenne & MS & 9 & $6,3,2,1$ weeks & 13.23 & 30 & 2.27 & 3.33 & NS \\
\hline L. perenne & WPBS & 10 & $6,3,2,1$ weeks & 34.01 & 100 & 2.94 & 10 & \\
\hline L. temulentum & MS & 425 & 10-12 day & 10.81 & $3(27)$ & 0.28 & 0.01 & $\mathrm{P} \leq 0.01$ \\
\hline L. temulentum & WPBS & 566 & 10-12 day & 17.63 & $23(70)$ & 1.3 & 0.04 & \\
\hline B. distachyon & MS & 50 & 3,1 weeks & 4.34 & 3 & 0.69 & 0.06 & $\mathrm{P} \leq 0.01$ \\
\hline B. distachyon & WPBS & 55 & 3,1 weeks & 9.25 & 16 & 1.73 & 0.29 & \\
\hline B. distachyon & MS & 43 & $3,2,1$ weeks & 27.09 & 1 & 0.04 & 0.02 & $\mathrm{P} \leq 0.01$ \\
\hline B. distachyon & WPBS & 47 & $3,2,1$ weeks & 41.09 & 18 & 0.44 & 0.38 & \\
\hline $\begin{array}{l}\text { F. arundina- } \\
\text { cea }\end{array}$ & MS & $\mathrm{n} / \mathrm{r}$ & $6,3,2,1$ weeks & 3.59 & 3 & 0.84 & $\mathrm{n} / \mathrm{r}$ & NS \\
\hline $\begin{array}{l}\text { F. arundina- } \\
\text { cea }\end{array}$ & WPBS & $\mathrm{n} / \mathrm{r}$ & $6,3,2,1$ weeks & 6.68 & 9 & 1.35 & $\mathrm{n} / \mathrm{r}$ & \\
\hline M. sinensis & MS & 9 & $6,2,2,1$ weeks & 9.97 & 0 & 0 & 0 & NS \\
\hline M. sinensis & WPBS & 15 & $6,2,2,1$ weeks & 36.73 & 25 & 0.68 & 1.67 & \\
\hline M. floridulus & MS & 8 & $6,2,2,1$ weeks & 12.66 & 0 & 0 & 0 & NS \\
\hline M. floridulus & WPBS & 25 & $6,2,2,1$ weeks & 28.07 & 1 & 0.04 & 0.04 & \\
\hline
\end{tabular}

(b) Comparison of adding or leaving out copper $(\mathrm{Cu})$ in infection and co-cultivation media using gus $\mathrm{A}$

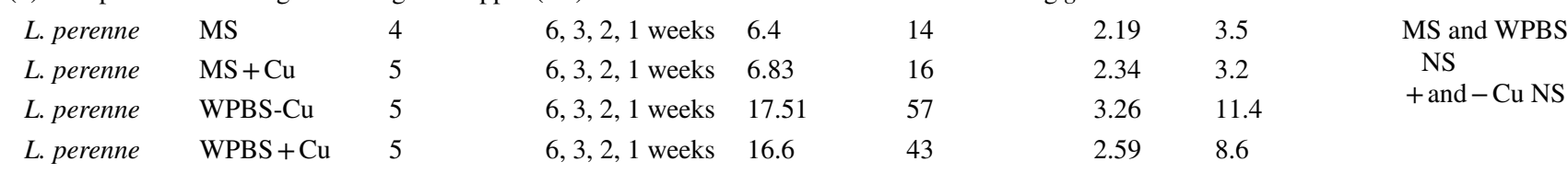

(c) Comparison of calli derived from shoot tips and OMM meristem tissue using genes of interest

\begin{tabular}{|c|c|c|c|c|c|c|c|c|}
\hline $\begin{array}{l}\text { F. arundina- } \\
\text { cea }\end{array}$ & WPBS & 68 & $6,2,1$ weeks & 11.22 & 16 & 1.43 & 0.24 & \multirow[t]{2}{*}{$\mathrm{P} \leq 0.05$} \\
\hline $\begin{array}{l}\text { F. arundina- } \\
\text { cea }\end{array}$ & WPBS OMM & 45 & $8,1.5$ weeks & 15.03 & 13 & 0.86 & 0.29 & \\
\hline L. perenne & WPBS & 74 & $5,2,1$ weeks & 9.64 & 17 & 1.76 & 0.23 & \multirow[t]{2}{*}{ NS } \\
\hline L. perenne & WPBS OMM & 19 & $5,2,1$ weeks & 20.05 & 11 & 0.55 & 0.58 & \\
\hline L. temulentum & WPBS & 1848 & $4-5,1$ weeks & 311.02 & 4 & 0.01 & 0.002 & \multirow[t]{2}{*}{$\mathrm{P} \leq 0.01$} \\
\hline L. temulentum & WPBS OMM & 321 & $3-5,1$ weeks & 70.55 & 12 & 0.17 & 0.037 & \\
\hline \multicolumn{9}{|c|}{ d) Comparison of callus culture regimes using genes of interest } \\
\hline B. distachyon & WPBS & 124 & 3,1 weeks & 18.18 & 29 & 1.6 & 0.23 & \multirow{3}{*}{$\begin{array}{c}3,1 \mathrm{wk} \text { and } \\
3,2,1 \mathrm{wk} \\
\mathrm{P} \leq 0.05\end{array}$} \\
\hline B. distachyon & WPBS & 88 & 4,1 weeks & 27.59 & 27 & 0.98 & 0.31 & \\
\hline B. distachyon & WPBS & 47 & $3,2,1$ weeks & 41.09 & 18 & 0.44 & 0.38 & \\
\hline L. perenne & WPBS & 45 & 4, 2, 1 weeks & 10.51 & 20 & 1.9 & 0.44 & \multirow[t]{2}{*}{ NS } \\
\hline L. perenne & WPBS & 39 & $5,2,1,1$ weeks & 40.99 & 56 & 1.37 & 1.44 & \\
\hline \multicolumn{9}{|c|}{ e) Comparison of vacuum treatment (vac) and immersion (imm) of calli using genes of interest } \\
\hline L. temulentum & MS vac & 110 & 10 day & 2.63 & $1(4)$ & 0.38 & 0.01 & \multirow{4}{*}{$\begin{array}{l}\text { MS and WPBS } \\
\mathrm{P} \leq 0.01 \\
\text { Vacuum and } \\
\text { immersion NS }\end{array}$} \\
\hline L. temulentum & MS imm & 154 & 10 day & 3.69 & $1(5)$ & 0.27 & 0.01 & \\
\hline L. temulentum & WPBS vac & 154 & 10 day & 4.71 & $6(19)$ & 1.27 & 0.04 & \\
\hline L. temulentum & WPBS imm & 220 & 10 day & 6.73 & $8(25)$ & 1.19 & 0.04 & \\
\hline \multicolumn{9}{|c|}{ f) Comparison of heat shock (HS) and vacuum treatment (vac) of calli using genes of interest } \\
\hline B. distachyon & WPBS HS & 29 & 4,1 weeks & 8.25 & 6 & 0.73 & 0.21 & \multirow[t]{2}{*}{$\mathrm{P}=0.054$} \\
\hline B. distachyon & WPBS vac & 29 & 4,1 weeks & 8.25 & 15 & 1.82 & 0.52 & \\
\hline
\end{tabular}

NS not significant, $\mathrm{n} / \mathrm{r}$ not recorded 

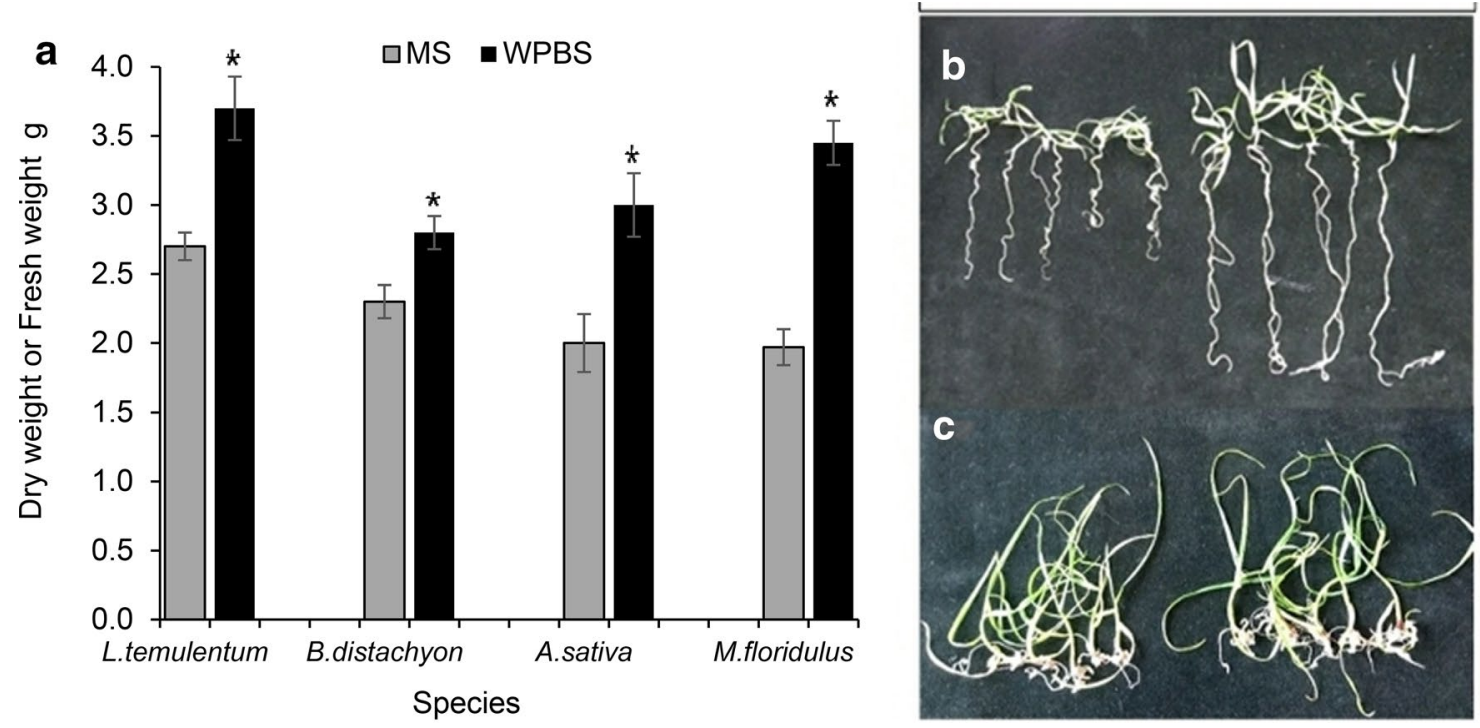

Fig. 1 a Mean dry weight of 100 seedlings of Lolium temulentum and Avena sativa after 3 weeks, Brachypodium distachyon after 6 weeks and fresh weight of individual plantlets of Miscanthus floridulus after 7 weeks cultured on MS or WPBS medium. Mean \pm sem.

\section{Lolium temulentum}

Transformation efficiency was low and variable, but with 10 to 12-day-old cultures there were significantly more transformed plants per replicate ( 25 embryos) using WPBS medium compared with MS medium (Table 3a, Suppl. Fig. 1k) ( $\mathrm{P} \leq 0.01)$. There was no overall significant difference in transformation efficiency with different callus induction periods on WPBS medium (Suppl. Fig. 4), but calli cultured for more than 5 weeks produced virtually no transformants, unless derived from OMM-derived meristems (Table 3c). These cultures produced significantly more transformants per explant and per replicate treatment than immature-embryo-derived calli of a similar age (both $\mathrm{P} \leq 0.01$ ), but not per g callus $(\mathrm{P} \leq 0.26)$.

Transformed calli regenerated readily on the RM medium (Fig. 7c) and GUS expression from pBRACT204 was high in transformed plants (Suppl. Figs. 5c, 6d). As a species L. temulentum was prone to produce non-regenerating calli and albino shoots, indicating somaclonal variation and a rapid loss of totipotency (Dalton and Thomas 1992). It was preferable therefore to use the youngest cultures possible. However, L. temulentum donor plants are susceptible to an endemic bacterial infection which contaminates some immature embryos and is visible after 6 days growth. Donor plants were grown from 'clean' embryos, but potential contamination precluded the use of fresh embryos, which were otherwise a relatively transformable explant (Suppl. Fig. 4).

Immersing plated calli with Agrobacterium suspension during the infection period (Table $3 \mathrm{e}$ ) was less effective than *-means significantly different from MS controls $\mathrm{p} \leq 0.01$ (Miscanthus $<0.025)$. In vitro seedlings from mature embryos cultured on MS (left) or WPBS ( right) medium b Brachypodium distachyon, c Lolium temulentum

vacuum infiltration of Agrobacterium suspension into gathered calli, but immersion was a simpler and gentler method.

\section{Brachypodium distachyon}

Immature embryos cultured for up to 7 days were transformable at a low efficiency but were too delicate to handle easily (data not shown). With normal callus induction, the number of transformed plants per replicate (1-2 g callus) of 3-2-1week and 3-1-week calli grown on WPBS medium was significantly higher than on MS medium $(\mathrm{P} \leq 0.01)$ (Table $3 \mathrm{a})$. The younger, high quality embryogenic callus from the 3-1week subculture regime also had a higher transformation efficiency than callus from the 4-1-week subculture regime (Table 3d). Transformation using the 3-week-10-day regime was unsuccessful (Suppl. Table 6a).

Transformed plants regenerated readily on the RM medium (Fig. 7d) and GUS was strongly expressed in plants transformed with pBRACT204 (Suppl. Figs. 5d, 6e). Transformation efficiency was significantly higher after vacuum infiltration than after heat shock treatment $(\mathrm{P} \leq 0.06)$ (Table 3f).

\section{Avena sativa, Oryza sativa, Zea mays}

Transformation in Avena was problematic as there were many non-transformed escaped plants, whether using paromomycin, hygromycin or PPT/Bialophos for selection (Suppl. Fig. 6h). GUS expressing calli and plants transformed with the construct pTOK233, were only recovered 

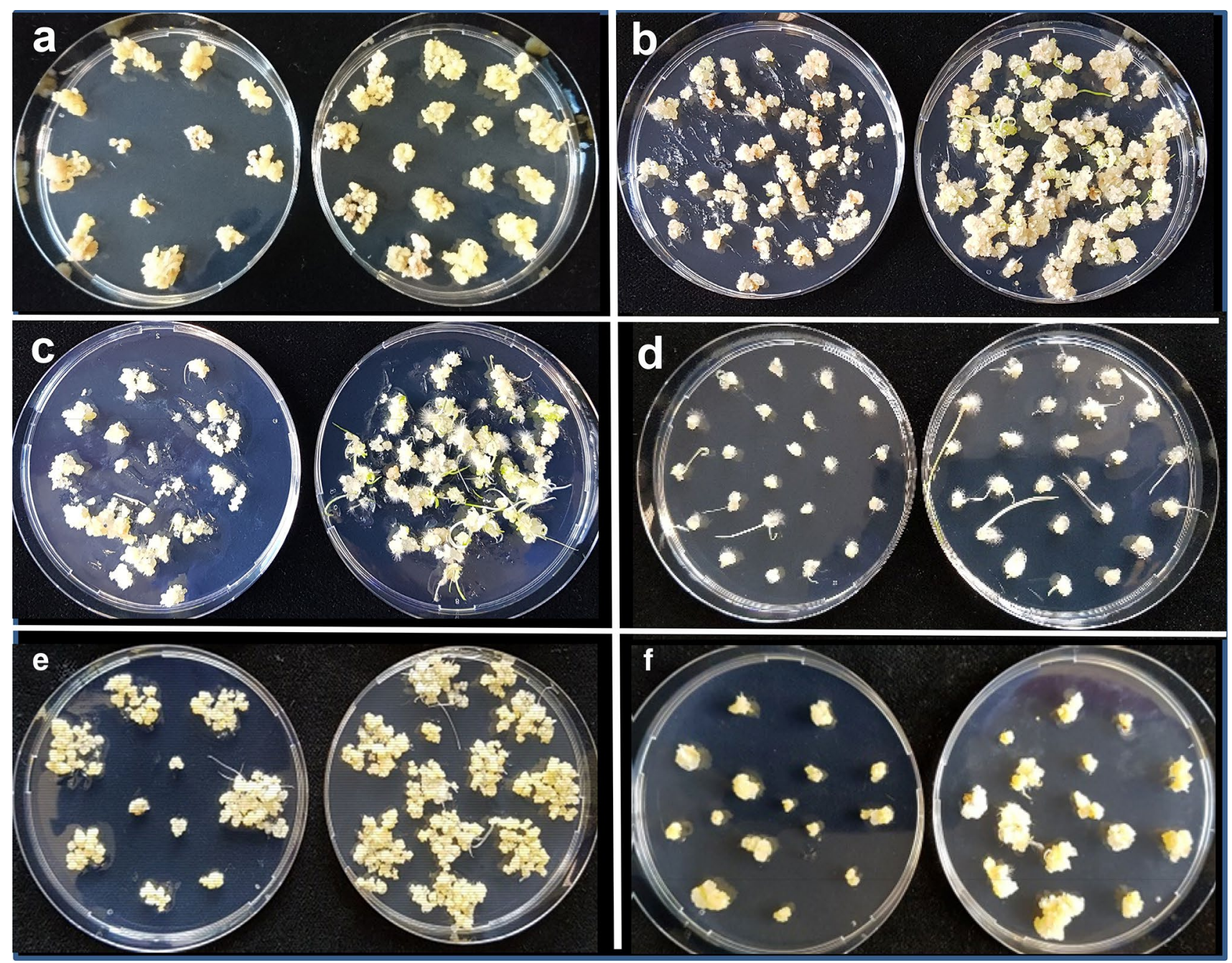

Fig. 2 Callus induction on MS control (left) and WPBS media (right): a Miscanthus floridulus shoot tip (ST) calli at 12 weeks, b Lolium perenne ST calli at 12 weeks, c Festuca arundinacea ST calli at 12 weeks, $\mathbf{d}$ Lolium temulentum immature embryo (IE) calli at

when paromomycin rather than hygromycin was used (Suppl. Fig. 5e) and hygromycin selection with pBRACT204 was unsuccessful. In transformations with the bar gene, which confers herbicide resistance, Avena leaves were assayed with $5 \mathrm{mgl}^{-1}$ PPT and the $\mathrm{pH}$ indicator chlorophenol red (Kramer et al. 1993). PPT-resistant leaves turned the medium yellow and the plants were subsequently shown to be PCR positive. PPT resistant plants were recovered after bombardment with the plasmid construct pUBA (ubi-bar) (Toki et al. 1992) (Suppl. Fig. 5f lower fifteen leaves), but not using pTF102 (CaMV35S-bar), (Suppl. Fig. 5f upper ten leaves), indicating that a strong selectable gene promoter and strong selection was required for successful transformation of this species.

The plasmid pTF102 was also used with $O$. sativa, but GUS expressing plants were only obtained using
12 days, e Brachypodium distachyon (IE) calli after 4 weeks, 1 week culture, f Avena sativa oat cv Bajka proliferated meristem calli at 5 weeks

embryogenic mature-embryo-derived callus because GUS expressing shoot-tip-derived calli were unable to regenerate (Suppl. Fig. 5g). Transformation of Z. mays shoot-tipderived callus with the same plasmid was also unsuccessful as the calli were unable to regenerate, but fresh immature embryos had been previously transformed using the MS based infection and co-cultivation medium (Suppl. Fig. 6g).

\section{Other grasses}

Three genotypes of $P$. arundinacea were transformed at the first attempt with pBRACT204 using hygromycin selection (Fig. 7e, Suppl. Fig. 6f) and pTOK233 using paromomycin selection (Fig. 7f), although GUS positive plants transformed with pBRACT204 expressed GUS more strongly (Suppl. Fig. 3h), than with pTOK233. D. cespitosa was 
Fig. 3 Growth of calli on MS control and WPBS medium a Net growth of established Miscanthus sinensis calli after two and five weeks culture. Mean $\pm \operatorname{sem}(n=4$ and 15.) *means significantly different $\mathrm{p} \leq 0.01, \mathbf{b}$ Growth of calli from 20 shoot tips of Festuca arundinacea, Lolium multiflorum, and L. perenne, and from $0.18 \mathrm{~g}$ Miscanthus sinensis callus. Mean \pm sem. *-means significantly different from MS controls $\mathrm{p} \leq 0.015$, $\mathrm{c}$ Growth of Lolium temulentum immature embryos during initial callus initiation. Mean fresh weight of 100 calli $\pm \operatorname{sem}(n=2-59)$, d Growth of shoot tip-derived Avena sativa (oat) callus over 25 days on MS control and WPBS medium. Mean \pm sem ( $\mathrm{n}=3$ and 5 respectively)
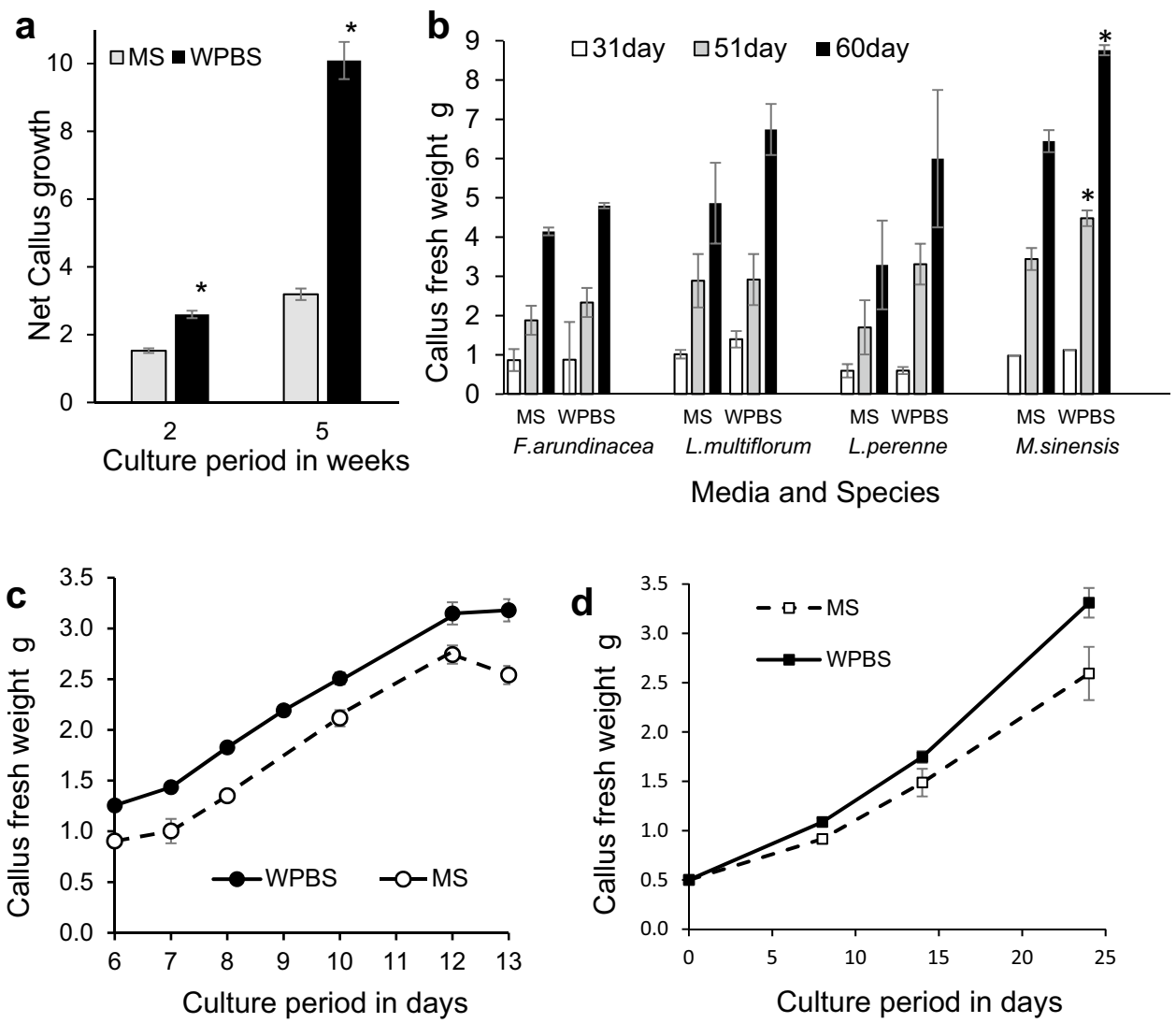

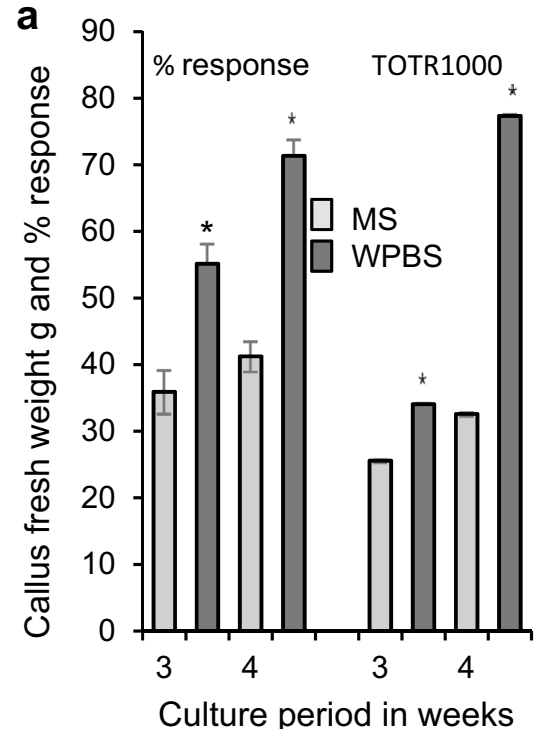

Culture period in weeks

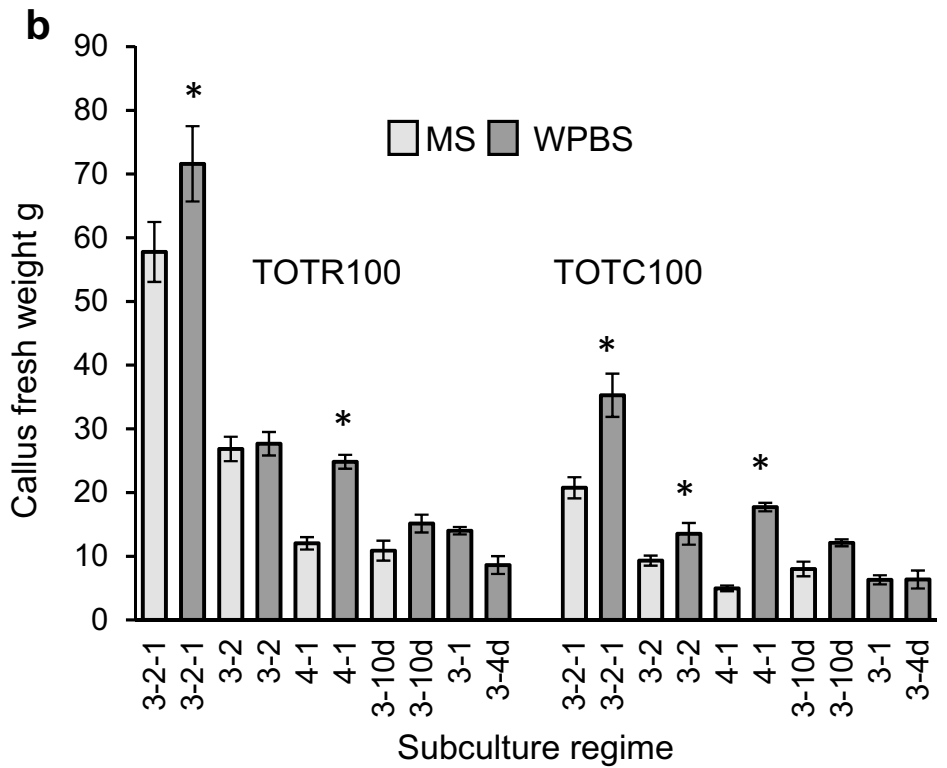

Fig. 4 a The effect of a three or four week initial culture period on the percentage of Brachypodium distachyon immature embryos developing embryogenic callus and the mean fresh weight of callus from 1000 responsive embryos (TOTR1000) on MS and WPBS medium. Means \pm sem, * indicates means that are significantly different from MS controls $\mathrm{P} \leq 0.01$. b Growth of embryogenic callus derived from immature embryos of Brachypodium distachyon under different subculture regimes on MS or WPBS medium. Mean fresh weight of 100 responsive (TOTR100) or cultured embryos (TOTC100) Means \pm sem, *indicates means that are significantly different from MS controls $\mathrm{P} \leq 0.05$ 
Fig. 5 a Proliferating meristems of Avena sativa (oat) on WPBSOMM medium, b Growth of callus after initiation from shoot tips of seedlings on WPBSMSO medium or meristem clusters from shoot tips precultured on WPBS-OMM media. Mean fresh weight from 100 shoot tips or meristem clusters, Mean $\pm \operatorname{sem}(n=5)$
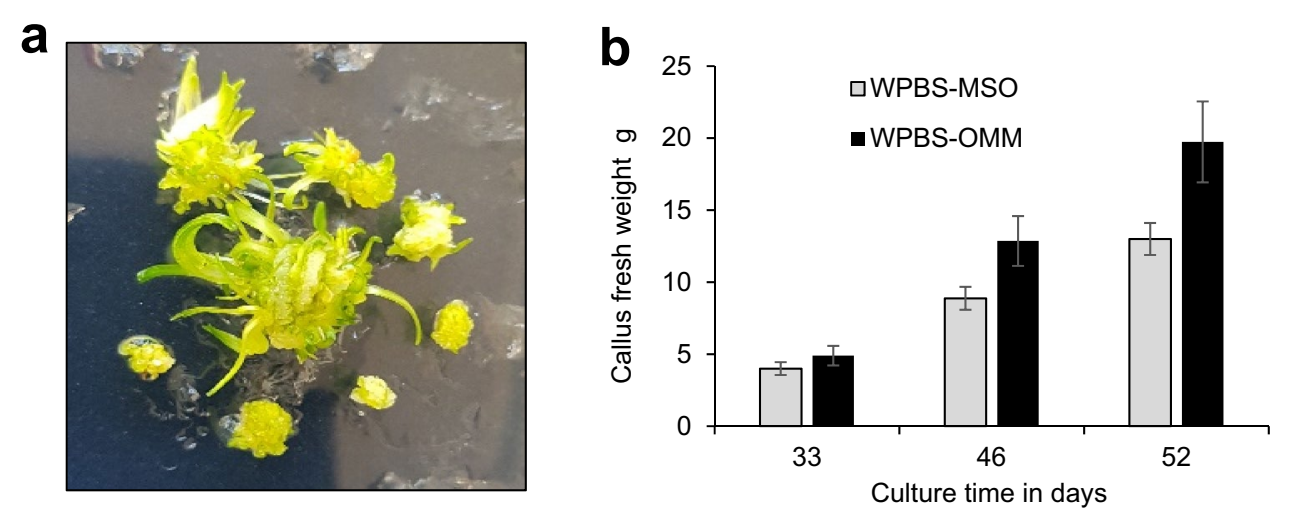
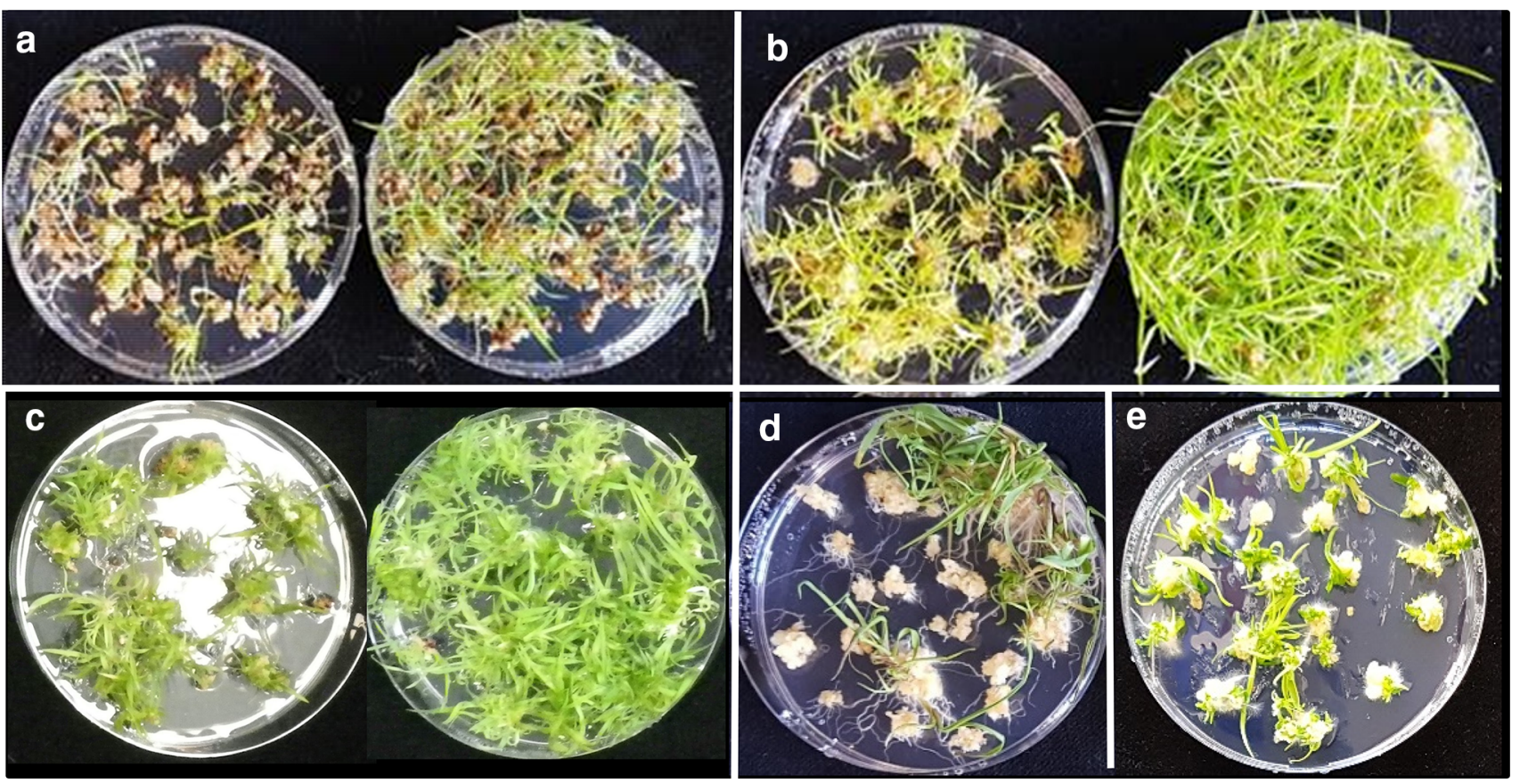

Fig. 6 Plant development on MS control (left) and WPBS (right) RM regeneration medium: a Brachypodium distachyon, $\boldsymbol{b}$ Lolium perenne, c Miscanthus sinensis and plant regeneration on WPBS RM only: $\mathbf{d}$ Phalaris arundinacea, e Avena sativa

also transformed with pBRACT204 at the first attempt and expressed GUS (Fig. 7g, Suppl. Figs. 5i, 6g).

The plasmid construct pBRACT204 was also successfully used with calli of $F$. arundinacea, F. rubra and A. stolonifera (Fig. 7h, Suppl. Fig. 5j), induced and grown over three subculture periods. A regime of 5-2-1-weeks or 4-2-2-1-weeks seemed ideal for most species and at least $2 \mathrm{~g}$ and up to $30 \mathrm{~g}$ of embryogenic callus per ten responding explants could be generated.

In a transformation experiment with $F$. arundinacea, L. perenne and L. multiflorum callus, (Fig. 3b) L. multiflorum was unsuccessful because the treated calli became overgrown with Agrobacterium (Suppl. Table 6g). Another experiment with $L$. multiflorum and $P$. pratensis calli failed due to contamination. Hygromycin, paromomycin or PPT resistant plants were therefore obtained from Agrobacterium-mediated transformations of thirteen species using WPBS media (Table 3, Suppl. Table 6) and GUS was expressed in all species except $M$. sacchariflorus. Transformed plants were also obtained by biolistic transformation of A. sativa, $F$. arundinacea, $M$. sinensis and $M$. floridulus (Suppl. Table 6g) using WPBS media. In addition, transgenic hygromycin resistant $L$. temulentum, $F$. arundinacea and $B$. distachyon cultures were rebombarded with additional GOI using the nptII marker gene and paromomycin selection, as in Buanafina et al. 2015 (Suppl. Table 6g). 

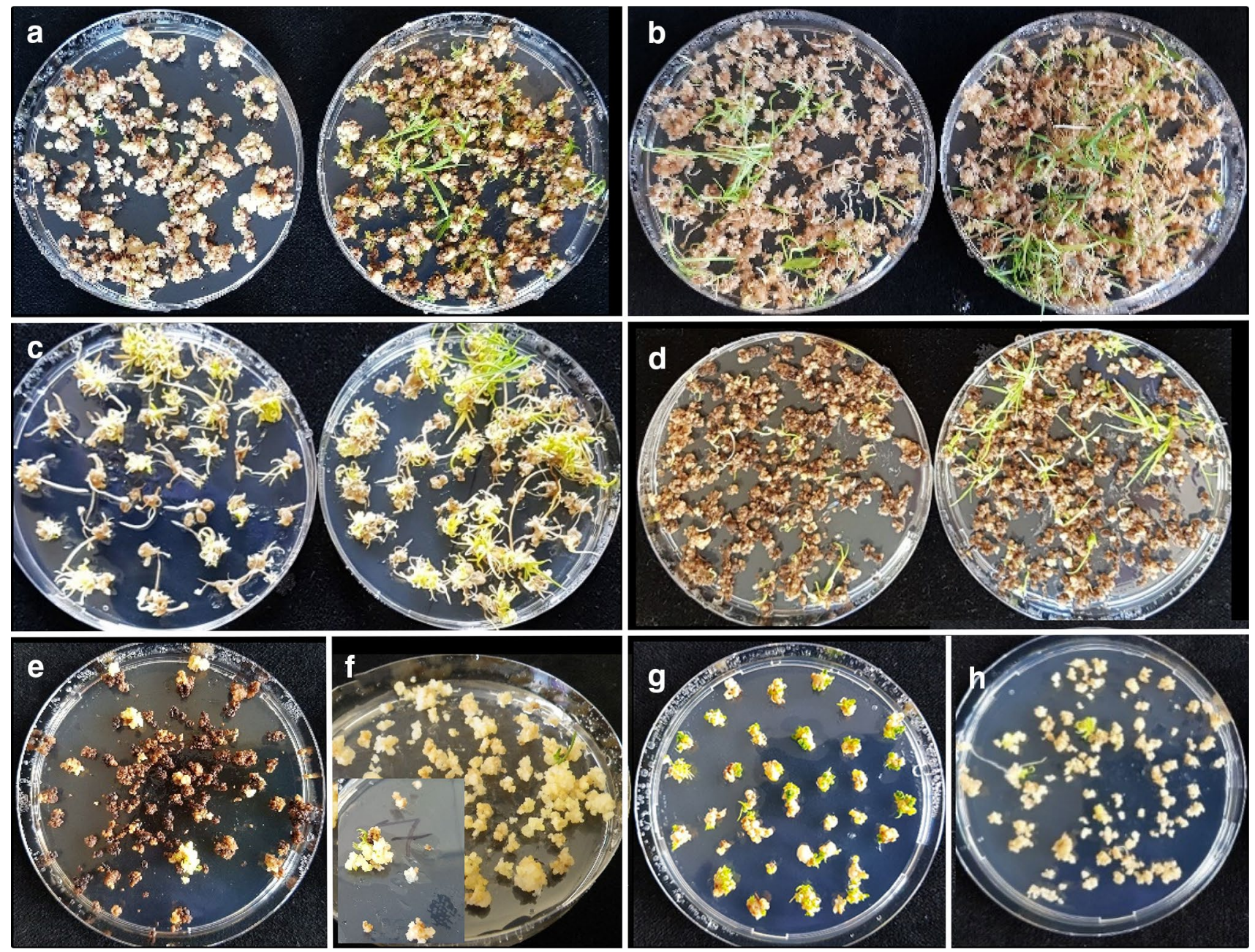

Fig. 7 Regeneration of transformed plants under hygromycin selection on MS control (left) and WPBS RM medium (right): a Miscanthus sinensis, b Lolium perenne, c Lolium temulentum, d Brach-

\section{WBPS medium increases transformed plant regeneration and rooting}

The RM medium (Table 2) was an effective plant regeneration medium but was improved further when based on WPBS rather than MS media. Calli of sixteen species regenerated well and calli of the thirteen transformed species developed shoots and roots under selection before transfer to WPBS-A based MSO or liquid MS1.5P (Miscanthus) maintenance/rooting medium (Suppl. Fig. 6 a-g). Rooted transformed plants of all the species were successfully transferred to soil (Suppl. Fig. $7 \mathrm{a}-\mathrm{f}$ ). ypodium distachyon, Regeneration on WPBS RM medium only: e Phalaris arundincaea with hygromycin and $\mathbf{f}$ with paromomycin, $\mathbf{g}$ Deschampsia cespitosa, $\mathbf{h}$ Agrostis stolonifera

\section{Discussion}

\section{Formulation of WPBS medium}

The compounds added to MS medium to produce WPBS medium, were either already present in MS medium at lower concentrations, or have been used previously as single additives, to improve embryogenic growth in specific species as described in the introduction.

While the composition of WPBS medium may appear complex, in effect it is easy to make as the additives are simply combined in a stock solution and added to MS medium 
with $75 \%$ macro-elements before autoclaving or filtersterilisation. The only complication is that myo-inositol needs to be omitted from callus induction medium as it can reduce Agrobacterium infectivity (Zhang et al. 2013), while Nawapan et al. (2009) found $2 \mathrm{mM}$ copper sulphate reduced Agrobacterium growth. Hence both myo-inositol and copper sulphate are omitted from WPBS based infection and co-cultivation media.

\section{Callus induction, growth and subculture regimes}

WPBS media were successfully used across sixteen species to produce suitable embryogenic calli for transformation, with only minor variations in the auxin and cytokinin concentrations in callus induction and selection media and with additional proline for Miscanthus species.

The use of WPBS medium reduced the time that tissues were in culture, which is particularly important in minimising somaclonal variation. This was achieved by decreasing the number of sub-cultures required to produce callus, particularly for Brachypodium transformation, while in L.temulentum it would be possible and probably preferable to transform fresh immature embryos if sterility could be ensured.

In Avena, the wide range of embryo maturity in panicles means that few embryos per panicle are suitable for culture. Shoot tips from sterile seedlings have been used Gasparis and Nadolska-Orczyk (2015), but de-husking seeds for sterilisation is time-consuming. Maqbool et al. (2002) developed $\mathrm{OMM}$ medium to induce meristematic clusters and were able to successfully directly transform them. While this was not repeatable in our laboratory, we found that proliferated meristems, particularly in Avena, but also in Festuca and Lolium, greatly increased the amount of embryogenic callus produced per explant and this approach may well be transferable to other species. However, in Oryza and Z. mays, regenerative embryogenic calli were produced only from embryos.

Using WPBS medium, transformable calli derived from Oryza embryos or shoot tips of perennial grass species could be grown and used within 9 to 12 weeks, although embryogenic callus induction in Miscanthus species remained slow compared with other genera. However, once established, Miscanthus calli grew well and remained regenerative for at least 8 months.

Quantitative determination of callus growth led to the conclusion that sub-culturing more than $0.5 \mathrm{~g}$ of callus to a $90 \mathrm{~mm}$ Petri-dish containing $25 \mathrm{ml}$ medium reduced callus growth rates. This probably represents the maximum plating density for callus of most species. Transformation efficiency was also greatly reduced by using calli older than 7 days from the last subculture, even in relatively slow growing species such as Miscanthus and Avena. In conclusion any callus induction regime should aim to produce calli within 3 months, sub-culture no more than $0.5 \mathrm{~g}$ callus per Petri-dish and transform callus no older than 7 days.

\section{Transformation protocol}

Using WPBS medium, plant transformation was improved in every species tested, either by increasing callus growth or decreasing the time in culture although significance was sometimes difficult to demonstrate with the transformation stage. However, overall the increased percentage of plants produced per gram of callus using WPBS based media across six species was significantly higher.

Unsuccessful transformations of L. multiflorum and $P$. pratensis were due to contamination and of $Z$. mays due to using shoot-tip-derived callus, but thirteen other species were transformed using the same basic protocol and WPBSbased media to induce calli, transform, select and regenerate plants. P. arundinacea and D. cespitosa calli were transformed in this way at the first attempt. The only differences were in callus induction explant, plant growth regulators for callus growth and sub-culture regime. The same infection, co-cultivation and regeneration media were highly effective in every species, although transformability and regenerative ability naturally differed between species and genotypes.

It is hoped that the use of this WPBS-based media and this general protocol may help to improve the general efficiency of grass and cereal transformation.

Acknowledgements I would like to express my deep gratitude to Phil Morris for all his invaluable help and advice in the preparation of this manuscript. In addition I thank Kan Wang, Iowa State University for pTF102/EHA105, Candida Nibau, IBERS for pBRACT204/AGL1, Toshihiko Komari, Japan Tobacco Inc. for pTOK233/LBA4404, Seiichi Toki, National Institute of Agrobiological Sciences, Japan for pUBA, Paul Robson, IBERS for pBKS, Marcia Buanafina, Penn State University, Rakesh Bhatia, Maurice Bosch, Lorenz Fuchs, Tim Langdon, Phil Morris, Candida Nibau, Paul Robson, IBERS for the opportunity to use their genes of interest, Marionette Alana, IRRI for IR-64 and IET4786 seed, Oumaya Bouchabké-Coussa, INRA for BD21-3 seed, the Maize Genetics Co-operation Stock Centre for A188 seed, IPK, Gatersleben for C8-A24 seed, and Ian Thomas, IBERS for Ba3081, WPBS and other cultivar seed and for creating my experiment database. I thank also Emma Timms-Taravella and Samantha Gill for their general assistance.

Author contributions SJD conceived the study, performed the experiments, analysed and interpreted the results and wrote the final manuscript.

Funding The Institute of Biological, Environmental and Rural Sciences (IBERS) is grant aided by the UK Biotechnology and Biological Sciences Research Council (BBSRC), under the Energy Grasses \& Biorefining Institute Strategic Programme (BBS/E/W/10963A01) and the EU project 'WATBIO' Development of improved perennial nonfood biomass and bioproduct crops for water stressed environments (FP7-311929). 
Open Access This article is licensed under a Creative Commons Attribution 4.0 International License, which permits use, sharing, adaptation, distribution and reproduction in any medium or format, as long as you give appropriate credit to the original author(s) and the source, provide a link to the Creative Commons licence, and indicate if changes were made. The images or other third party material in this article are included in the article's Creative Commons licence, unless indicated otherwise in a credit line to the material. If material is not included in the article's Creative Commons licence and your intended use is not permitted by statutory regulation or exceeds the permitted use, you will need to obtain permission directly from the copyright holder. To view a copy of this licence, visit http://creativecommons.org/licenses/by/4.0/.

\section{References}

Bettany AJE, Dalton SJ, Timms E, Manderyck B, Dhanoa MS, Morris P (2003) Agrobacterium tumefaciens-mediated transformation of Festuca arundinacea (Schreb.) and Lolium multiflorum Lam. Plant Cell Rep 21:437-444

Buanafina MM, Dalton SJ, Langdon T, Timms-Taravella E, Shearer EA, Morris P (2015) Functional co-expression of a fungal ferulic acid esterase and a $\beta-1,4$ endoxylanase in Festuca arundinacea (tall fescue) modifies post-harvest cell wall deconstruction. Planta 242:97-111

Choi HW, Lemaux PG, Cho MJ (2001) High frequency of cytogenetic aberration in transgenic oat (Avena sativa L.) plants. Plant Sci 160:763-772

Dalton SJ (2013) Biotechnology of Miscanthus. In: Jain SM, Gupta SD (eds) Biotechnology of neglected and underutilized crops. Springer, Dordrecht, pp 243-294

Dalton SJ, Thomas ID (1992) A statistical comparison of various factors on embryogenic proliferation, morphogenesis and regeneration in Lolium temulentum cell suspension colonies. Plant Cell, Tissue Organ Cult 30:15-29

Dalton SJ, Bettany AJE, Timms E, Morris P (1998) Transgenic plants of Lolium multiflorum, Lolium perenne, Festuca arundinacea and Agrostis stolonifera by silicon carbide fibre-mediated transformation of cell suspension cultures. Plant Sci 132:31-43

Dalton SJ, Bettany AJE, Timms E, Morris P (1999) Co-transformed, diploid Lolium perenne (perennial ryegrass), Lolium multiflorum (Italian ryegrass) and Lolium temulentum (darnel) plants produced by microprojectile bombardment. Plant Cell Rep 18:721-726

Dalton SJ, Bettany AJE, Bhat V, Gupta MG, Bailey K, Timms E, Morris $\mathrm{P}$ (2003) Genetic transformation of Dichanthium annulatum (Forssk) - an apomictic tropical forage grass. Plant Cell Rep 21:974-980

Dalton SJ, Bosch M, Robson PR, Donnison IS. (2011) Neomycin phosphotransferase gene (nptII) as a selectable marker for Brachypodium BD21. 1st European Brachypodium Workshop, Versailles, France.

Finer JJ, Vain P, Jones MW, McMullen MD (1992) Development of the particle inflow gun for DNA delivery to plant cells. Plant Cell Rep 11:323-328

Frame BR, Shou H, Chikwamba RK, Zhang Z, Xiang C, Fonger TM, Pegg SM, Li B, Nettleton DS, Pei D, Wang K (2002) Agrobacterium tumefaciens-mediated transformation of maize embryos using a standard binary vector system. Plant Physiol 129:13-22

Gasparis S, Nadolska-Orczyk A (2015) Oat (Avena sativa L.). Methods Mol Biol 1223:143-153

Ha CD, Lemaux PG, Cho MJ (2001) Stable transformation of a recalcitrant Kentucky bluegrass (Poa pratensis L.) Cultivar using mature seed-derived highly regenerative tissues. In Vitro Cell Dev Biol Plant 37:6-11
Harwood WA, Bartlett JG, Alves SC, Perry M, Smedley MA, Leyland N, Snape JW (2009) Barley transformation using Agrobacteriummediated techniques. Methods Mol Biol 478:137-147

Hiei Y, Ohta S, Komari T, Kumashiro T (1994) Efficient transformation of rice (Oryza sativa L.) mediated by Agrobacterium and sequence analysis of the boundaries of the T-DNA. Plant J 6:271-282

Holme IB, Krogstrup P, Hansen J (1997) Embryogenic callus formation, growth and regeneration in callus and suspension cultures of Miscanthus $\times$ ogiformis Honda 'Giganteus' as affected by proline. Plant Cell, Tissue Organ Cult 50:203-210

Hwang OJ, Cho MA, Han YJ et al (2014) Agrobacterium-mediated genetic transformation of Miscanthus sinensis. Plant Cell, Tissue Organ Cult 117:51-63

Ishida Y, Saito H, Ohta S, Hiei Y, Komari T, Kumashiro T (1996) High efficiency transformation of maize (Zea mays L.) mediated by Agrobacterium tumefaciens. Nat Biotechnol 14:745-750

Kramer C, DiMaio J, Carswell GK, Shillito RD (1993) Selection of transformed protoplast-derived Zea mays colonies with phosphinothricin and a novel assay using the $\mathrm{pH}$ indicator chlorophenol red. Planta 190:454-458

Maqbool S, Zhong H, El-Maghraby Y et al (2002) Competence of oat (Avena sativa $\mathrm{L}$.) shoot apical meristems for integrative transformation, inherited expression, and osmotic tolerance of transgenic lines containing hval. Theor Appl Genet 105:201-208

Murashige T, Skoog F (1962) A revised medium for rapid growth and bioassays with tobacco tissue culture. Physiol Plant 15:473-497

Nawapan S, Charoenlap N, Charoenwuttitam A, Saenkham P, Mongkolsuk S, Vattanaviboon P (2009) Functional and expression analyses of the cop operon, required for copper resistance in Agrobacterium tumefaciens. J Bacteriol 191:5159-5168

Patel M, Dewey RE, Qu R (2013) Enhancing Agrobacterium tumefaciens-mediated transformation efficiency of perennial ryegrass and rice using heat and high maltose treatments during bacterial infection. Plant Cell, Tissue Organ Cult 114:19-29

Pawar B, Kale P, Bahurupe J, Jadhav A, Kale A, Pawar S (2015) Proline and glutamine improve in vitro callus induction and subsequent shooting in rice. Rice Sci 22:283-289

Pepó P, Tóth S (2003) The role of nitrogen and phosphorus source in Miscanthus in vitro cultures. Cereal Res Commun 33:549-552

Robson P, Dalton SJ, Morris P (2004) The challenge of reproduction. IGER Innovations 8:12-14

Shri M, Rai A, Verma PK, Misra P, Dubey S, Kumar S, Verma S, Gautam N, Tripathi RD, Trivedi PK, Chakrabarty D (2013) An improved Agrobacterium-mediated transformation of recalcitrant indica rice (Oryza sativa L.) cultivars. Protoplasma 250:631-636

Thole V, Vain P (2012) Agrobacterium-mediated transformation of Brachypodium distachyon. Methods Mol Biol 847:137-149

Toki S, Takamatsu S, Nojiri C, Ooba S, Anzai H, Iwata M, Christensen AH, Quail PH, Uchimiya H (1992) Expression of a maize ubiquitin gene promoter-bar chimeric gene in transgenic rice plants. Plant Physiol 100:1503-1507

Vogel J, Hill T (2008) High-efficiency Agrobacterium-mediated transformation of Brachypodium distachyon inbred line Bd21-3. Plant Cell Rep 27:471-478

Wang Z, Hopkins A, Mian R (2001) Forage and turf grass biotechnology. Crit Rev Plant Sci 20(6):573-619

Wang X, Yamada T, Kong F-J, Abe Y, Hoshino Y, Sato H, Takamizo T, Kanazawa A, Yamada T (2011) Establishment of an efficient in vitro culture and particle bombardment-mediated transformation systems in Miscanthus sinensis Anderss., a potential bioenergy crop. GCB Bioenergy 3:322-332

Xi J, Patel M, Dong S, Que Q, Qu R (2018) Acetosyringone treatment duration affects large T-DNA molecule transfer to rice callus. BMC Biotechnol 18:48

Yoo JH, Seong ES, Ghimire BK et al. (2018) Establishment of Miscanthus sinensis with decreased lignin biosynthesis by 
Agrobacterium-mediated transformation using antisense COMT gene. Plant Cell, Tissue Organ Cult 133:359-369

Zhang WJ, Dewey RE, Boss W, Phillippy BQ, Qu R (2013) Enhanced Agrobacterium-mediated transformation efficiencies in monocot cells is associated with attenuated defense responses. Plant Mol Biol 81:273-286
Publisher's Note Springer Nature remains neutral with regard to jurisdictional claims in published maps and institutional affiliations. 